University for Business and Technology in Kosovo

UBT Knowledge Center

UBT International Conference

2018 UBT International Conference

Oct 27th, 3:15 PM - 4:45 PM

\title{
Investigation of Production of Brick with Waste Coal Powder
}

\section{Additive}

\author{
Mehmedi Vehbi Gökçe \\ Nigde Ömer Halisdemir University, vgokce@ohu.edu.tr \\ Semiha Akçaözoğlu \\ Nigde Ömer Halisdemir University, sakcaozoglu@ohu.edu.tr \\ Besian Sinani \\ University for Business and Technology, besian.sinani@ubt-uni.net
}

Follow this and additional works at: https://knowledgecenter.ubt-uni.net/conference

Part of the Civil and Environmental Engineering Commons

\section{Recommended Citation}

Gökçe, Mehmedi Vehbi; Akçaözoğlu, Semiha; and Sinani, Besian, "Investigation of Production of Brick with Waste Coal Powder Additive" (2018). UBT International Conference. 56.

https://knowledgecenter.ubt-uni.net/conference/2018/all-events/56

This Event is brought to you for free and open access by the Publication and Journals at UBT Knowledge Center. It has been accepted for inclusion in UBT International Conference by an authorized administrator of UBT Knowledge Center. For more information, please contact knowledge.center@ubt-uni.net. 


\title{
Investigation of Production of Brick with Waste Coal Powder Additive
}

\author{
Mehmedi Vehbi Gökçe ${ }^{1}$, Semiha Akçaözoğlu ${ }^{1}$, Besian Sinani ${ }^{2}$ \\ ${ }^{1}$ Department of Architecture, Faculty of Architecture, Nigde Ömer Halisdemir \\ University, Nigde, Turkey \\ ${ }^{1}$ Department of Architecture, Faculty of Architecture, Nigde Ömer Halisdemir \\ University, Nigde, Turkey \\ ${ }^{2}$ Department of Civil Engineering, University for Business and Technology, Kosovo \\ vgokce@ohu.edu.tr, sakcaozoglu@ohu.edu.tr \\ besian.sinani@ubt-uni.net
}

\begin{abstract}
Wastes in coal quarries and coal power plants are significant issues. Coal washing plant tailings as waste coal powder is one of these issues. Today, their ecological and economical utilization, control and management are of main subjects for ongoing researches throughout the world. On the other hand, researchers still carry out intense investigations on the production of lightweight and sustainable products for construction industry. In Turkey, approximately 20 coal mines and 1 coal power plant do have coal washing plant. In this study, waste coal powder obtained from Soma, Manisa were replaced with clay obtained from Niğde Kolsuz Region in amount of $10 \%, 20 \%$ and $30 \%$ by weight and fired at $1000^{\circ} \mathrm{C}$ to produce bricks. Unit weight, compressive strength, flexural tensile strength and water absorption tests were carried out on the samples. Experimental results showed that the addition of coal powder at the replacement ratio of $10 \%$ increased the compressive strength and flexural tensile strength of the samples. Use of produced samples in the construction industry will provide produce of high strength bricks of developed features besides contributing to the utilization of coal powder by recycling.
\end{abstract}

Keywords: Brick, Kolsuz clay, coal powder, compressive strength, flexural-tensile strength.

\section{Introduction}

Brick, one of the oldest building materials of the history of civilization has come up to today saving its significance for the construction industry against the other materials and covered a wide range of area of utilization. Brick has a place in traditional construction systems since it has qualifications, such as its structure, physical and load-bearing characteristics, to meet a number of requirements in the construction industry.

Today, alternative building materials to brick are being produced with the use of developed technologies in the construction industry. However, bricks produced by using natural and recyclable sources remains as a significant building component for sustainable and energy effective design. For this purpose, it stands as an important task to improve its prevalent features and produce it more economically. To reach to this goal, researchers are conducting studies which miscellaneous additives and/or industrial by-products are used in. In the literature, there are studies in which a variety of raw and waste materials such as fly ash, hematite, marble powder, volcanic tuff, quartz, diatomite, siderite, red mud and coal powder are used to improve features of bricks [1-4]. 
Bideci and Sall Bideci [5], investigated usability of diatomite in brick production. For this purpose, they added diatomite into the brick paste at ratios of $10 \%, 20 \%$ and $30 \%$ by weight and fired the bricks at temperatures $800^{\circ} \mathrm{C}, 900^{\circ} \mathrm{C}$ and $1000^{\circ} \mathrm{C}$. They reported that the samples with $20 \%$ diatomite addition and fired at $900^{\circ} \mathrm{C}$ yielded positive results.

In another study, usability of Etibor, Kurka Borax Plant concentrator wastes in the production of pressed brick as element was investigated [6]. Bricks were produced by adding two different boron wastes at ratios of 5 and $20 \%$ to the brick blend. Samples were tested for cooking capabilities, post-cooking compressive strengths, end-point flexural strengths, water absorption and brittleness. It was reported that boron wastes significantly decreased baking temperatures, water absorption values and brittleness properties of the samples.

Bentli et al. [7], studied usability of fly ash from thermal power plants in production of brick as additive. Fly ash obtained from Seyitömer thermal power plant was used at ratios between $2.5 \%$ and $15 \%$. Fly ash addition did not cause a distinct change in drying, cooking and overall contraction though it caused unit weight to increase slightly. Strength and water absorption values were determined to have decreased.

Çelik et al. [8], produced bricks with addition of certain amounts of pumice to clay paste. According to the test results, addition of pumice $1 \mathrm{~mm}$ in size increased the compressive strength of the samples by about $36 \%$ while addition of pumice $2 \mathrm{~mm}$ in size caused a decrease in the strength by about $16 \%$. It was reported that the samples that were produced were found to be applicable in the construction industry.

In this study, some physical and mechanical characteristics of bricks produced using coal powder as additive. By using waste coal powder as a cheap raw material, waste material would be revalorised as an economic input and storage costs would be decreased besides features of the standard bricks would be improved.

\section{Materials and Methods}

Clay obtained from Kolsuz region (Niğde, Turkey) and used in the study are found in Kizılbayır Formation. Kizılbayır Formation is composed, from bottom to the top, of a loose cemented conglomerate, red green mudstone-claystone and lenticular pebble layer respectively. Granules in Kolsuz clay are not well-bonded with each other but are colligated by means of calcite, silica and iron oxide cement. The gravels of the unit are mostly composed of sandstone, greywacke, claystone, limestone, mam, volcanic rocks, grandoritic, gabbro, quartzite, chert and serpentinite. Metaphoric rock fragments are also observed in some places.

Petrographic studies showed that rocks (Kolsuz Clay) obtained from Kizılbayır Formation consisted of feldspar, quartz, calcite, volcanic rock fragments, magmatic rock fragments (gabbro serpentinite), metamorphic rock fragments (quartzite), carbonaceous rock fragments (micritic limestone, mam) and clastic sedimentary rock fragments (sandstone, greywacke, claystone), and calcium carbonate was determined to be the binding agent nearly in all rocks [9]. Clay from quarries in Kolsuz region was ground by means of a ring mill, and sifted through a $500 \mu \mathrm{m}$ square mesh sieve (Fig. 1). The chemical composition of the clay was given in Table 1. 


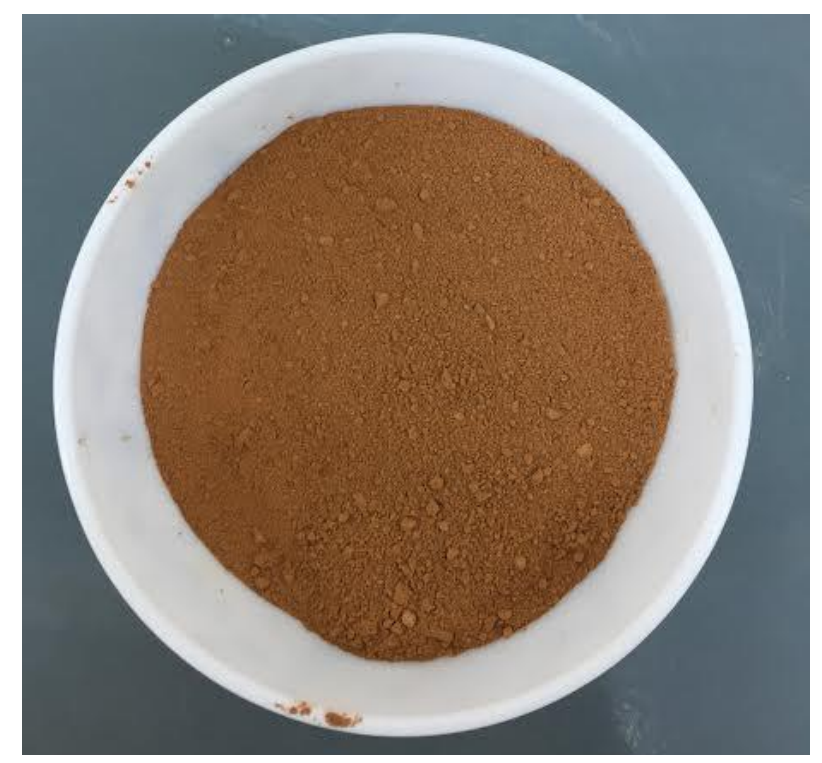

Fig. 1. Kolsuz clay

Table 1. Chemical properties of Kolsuz clay

\begin{tabular}{lccccccccc}
\hline Oxide $(\%)$ & $\mathrm{SiO}_{2}$ & $\mathrm{Al}_{2} \mathrm{O}_{3}$ & $\mathrm{Fe}_{2} \mathrm{O}_{3}$ & $\mathrm{CaO}$ & $\mathrm{MgO}$ & $\mathrm{SO}_{3}$ & $\mathrm{Na}_{2} \mathrm{O}$ & $\mathrm{K}_{2} \mathrm{O}$ & LOI \\
Clay & 50.97 & 11.58 & 6.67 & 8.4 & 3.9 & 0.1 & 1.83 & 2.31 & 13.63 \\
\hline
\end{tabular}

Coal washing plant tailings were obtained from a washing plant in Soma, Manisa, Turkey (Fig 2). Waste coal powder was also ground in a ring mill, sifted through a $500 \mu \mathrm{m}$ square mesh sieve and added into the mixtures. Carbon results of coal powder were given in Table 2. 


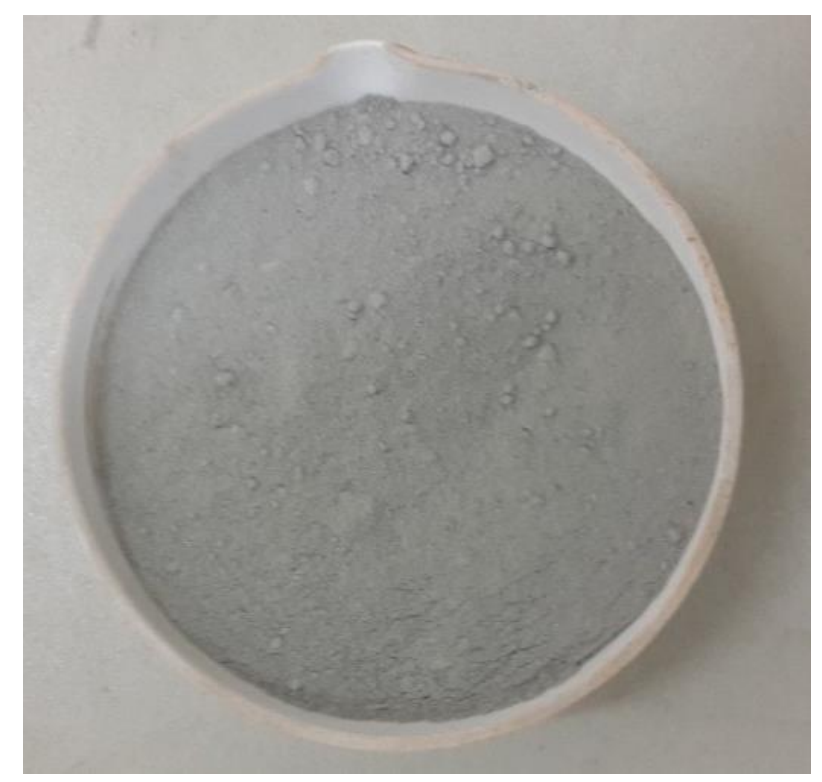

Fig. 2. Waste coal powder

Table 2. Carbon results

\begin{tabular}{lcc}
\hline & Total carbon $(\mathrm{mg} / \mathrm{L})$ & Organic carbon $(\mathrm{mg} / \mathrm{L})$ \\
\hline İmbat & 179,8 & 146,9 \\
Işılar & 143,3 & 166,6 \\
Dereköy & 185,6 & 145,2 \\
\hline
\end{tabular}

Mixtures were prepared by adding waste coal powder at ratios of $10 \%, 20 \%$ and $30 \%$ by weight in addition to control pastes prepared only from clay. Compositions of mixtures were given in Table 3.

Table 3. Composition of the mixtures

\begin{tabular}{ccccc}
\hline Mixture & $\begin{array}{c}\text { Clay } \\
(\mathrm{g})\end{array}$ & $\begin{array}{c}\text { Coal powder } \\
(\mathrm{g})\end{array}$ & $\begin{array}{c}\text { Water } \\
(\mathrm{g})\end{array}$ & $\begin{array}{c}\text { Firing temperature } \\
\left({ }^{\circ} \mathrm{C}\right)\end{array}$ \\
\hline M0 & 1000 & - & 200 & 1000 \\
M10 & 1000 & 100 & 170 & 1000 \\
M20 & 1000 & 200 & 180 & 1000 \\
M30 & 1000 & 300 & 200 & 1000 \\
\hline
\end{tabular}

Mixtures were paced into moulds 40x40x160 mm in size, and kept in the laboratory medium for 24 hours to let them tighten enough to be removed from moulds. After 24 hours, they were removed and kept in drying-oven at $100 \pm 2^{\circ} \mathrm{C}$ for another 24 hours to allow the samples to release the water contained in the paste. Brick samples were placed into an electric furnace heated to $1000 \pm 5{ }^{\circ} \mathrm{C}$ at a temperature increase rate of $8{ }^{\circ} \mathrm{C} / \mathrm{min}$, and fired for a period of 24 hours. After the samples were cooled off to the room temperature, then compressive strength, flexural strength tests and measurements for unit weight and water absorption values were conducted. Compressive and flexural strength tests were conducted in accordance with the standard TS EN 1015-11 [10], and water absorption values were measured in accordance with TS 3624 [11]. 


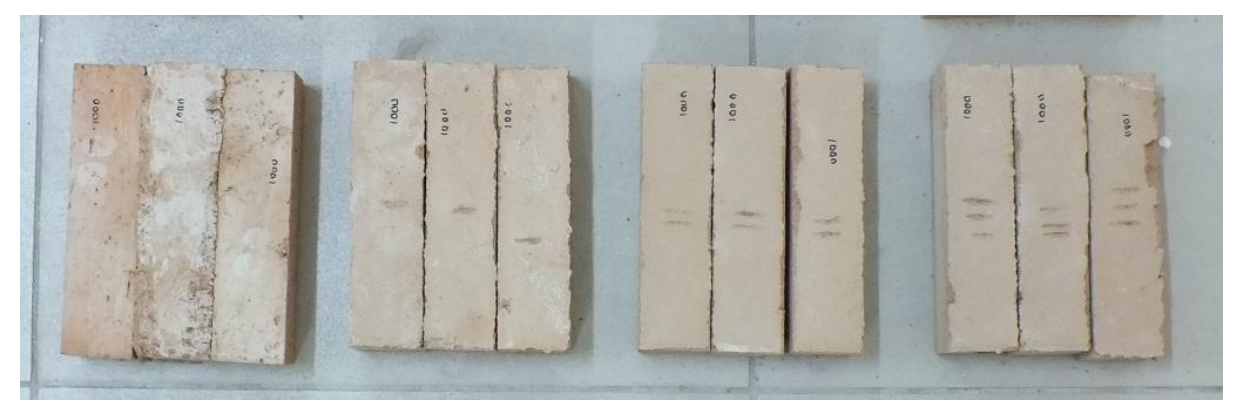

Fig. 3. Specimens with coal powder additive (from left to right M0, M10, M20 and M30)

\section{Results and Discussion}

Unit weights, compressive and flexural strengths of the produced samples were given in Table 4.

Table 4. Unit weights, compressive and flexural tensile strengths of the specimens

\begin{tabular}{cccc}
\hline Mixture & $\begin{array}{c}\text { Unit weight } \\
\left(\mathrm{g} / \mathrm{cm}^{3}\right)\end{array}$ & $\begin{array}{c}\text { Compressive strength } \\
\left(\mathrm{N} / \mathrm{mm}^{2}\right)\end{array}$ & $\begin{array}{c}\text { Flexural tensile strength } \\
\left(\mathrm{N} / \mathrm{mm}^{2}\right)\end{array}$ \\
\hline M0 & 1.77 & 25.8 & 1.79 \\
M10 & 1.71 & 29.7 & 2.11 \\
M20 & 1.63 & 23.5 & 1.61 \\
M30 & 1.54 & 18.6 & 1.72 \\
\hline
\end{tabular}

\section{Unit Weight}

When Table 4 examined, it is seen that unit weights of the samples with waste coal powder additive change between $1.54-1.71 \mathrm{~g} / \mathrm{cm}^{3}$. Unit weights decrease with increasing amount of coal powder additive. This is due to the fact that coal powder additive has undergone ignition loss during firing procedure and thus left the paste under firing. The relationship diagram of the coal powder with unit weights were given in Figure 4. 


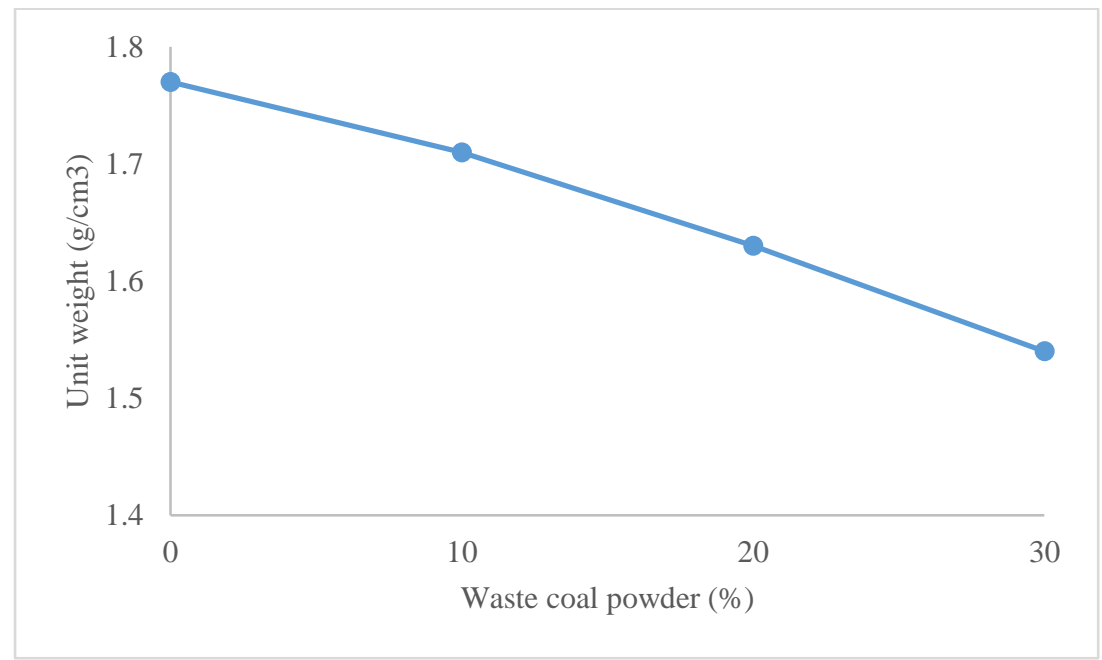

Fig. 4. The effect of coal powder additive on the unit weights

\section{Compressive Strength}

As seen in Table 4, control samples produced solely from clay and at $1000{ }^{\circ} \mathrm{C}$ yielded the compressive strength as $25,8 \mathrm{~N} / \mathrm{mm}^{2}$. Those of the samples with waste coal powder varies between 18.6 and $29.7 \mathrm{~N} / \mathrm{mm}^{2}$. Strength of the samples with $10 \%$ coal powder was determined to be higher than control samples.

As shown in Figure 5, samples with $10 \%$ coal additive exhibited higher strength than those with other replacement ratios. This result suggests that $10 \%$ coal powder additive and $1000{ }^{\circ} \mathrm{C}$ firing temperature bear a positive effect for a high strength brick production. Though coal powder replacement higher than $10 \%$ rate does not have a strength-rising effect on the samples it is suggestible that a replacement ratio between $20 \%$ and $30 \%$ is proper to produce bricks that have moderate compressive strength (at about a level of $20 \mathrm{~N} / \mathrm{mm}^{2}$ ) and cost. Increased coal powder ratio is certain to contribute positively to heat and sound insulation properties of the bricks in spite of their reducing effects in compressive strength. These impacts could be themes of further studies. 


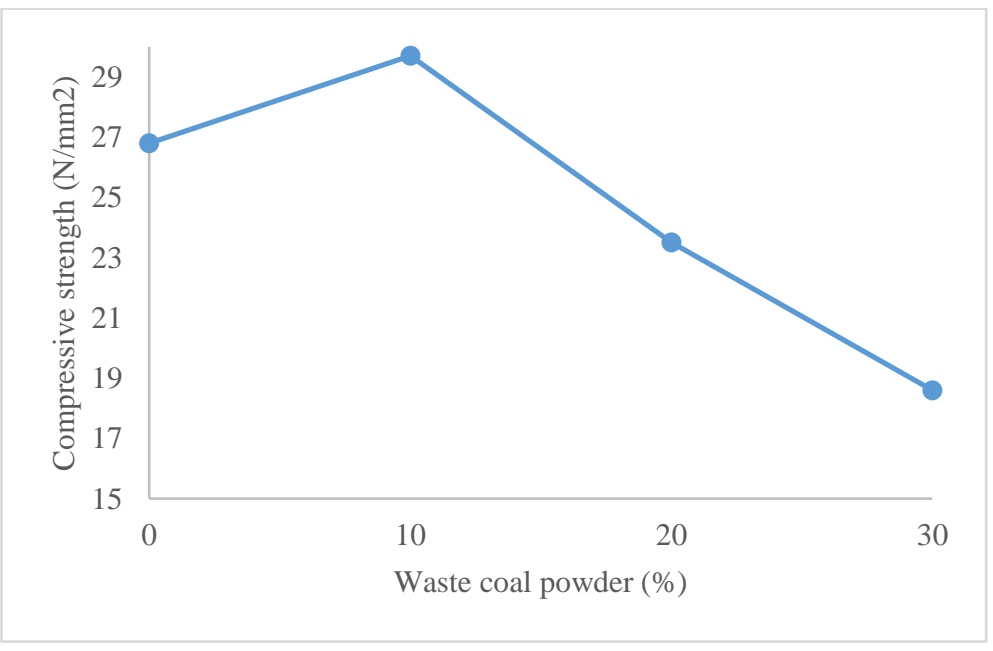

Fig. 5. The effect of coal powder replacement on the compressive strengths.

\section{Flexural Tensile Strength}

Flexural strengths of the samples exhibit parallel results to the compressive strengths. When the values given in Table 4 and Figure 6 are studied, it is observed that flexural strengths of the samples with $10 \%$ coal powder additive have yielded higher values than those of the control samples. As the coal powder ratio was increased to 20 and $30 \%$, flexural tensile strength was observed to have decreased. Thus, it was concluded that $10 \%$ ratio of coal powder additive could be suggested to be used to produce bricks of high compressive and flexural strengths since both had an increasing effect on these two parameters.

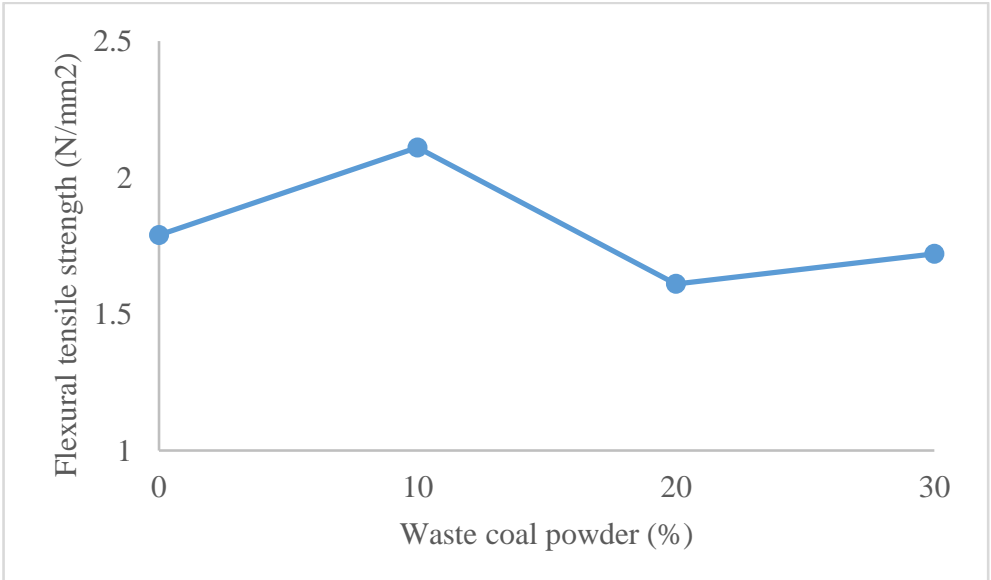

Fig. 6. The effect of coal powder replacement on the flexural tensile strength

\section{Water Absorption Ratio}

To measure water absorption ratios of the samples, each sample was first dried in an electric oven for 24 hours, and then they were weighed. Then, dried samples were kept in water for another 24 
hours and finally, and saturated weights were measured. Water absorption ratios by weight were given in Table 5 and Figure 7.

Table 5. Water absorption ratios of the specimens

\begin{tabular}{cc}
\hline Mixture & $\begin{array}{c}\text { Water absorption ratio } \\
\text { by weight }(\%)\end{array}$ \\
\hline M0 & 19.4 \\
M10 & 20.2 \\
M20 & 23.3 \\
M30 & 27.7 \\
\hline
\end{tabular}

By Table 5 and Figure 7, it could be seen that water absorption ratios of the samples with coal powder vary between 20.2 and $27.7 \%$ while that of control samples are $19.4 \%$. as the coal powder amount in mixtures increased, water absorption ratios did increase as well. This shows that coal powder additive has increased the porosity of the samples. However, water absorption value for the samples with $10 \%$ coal powder additive was determined to have been close to the control samples.

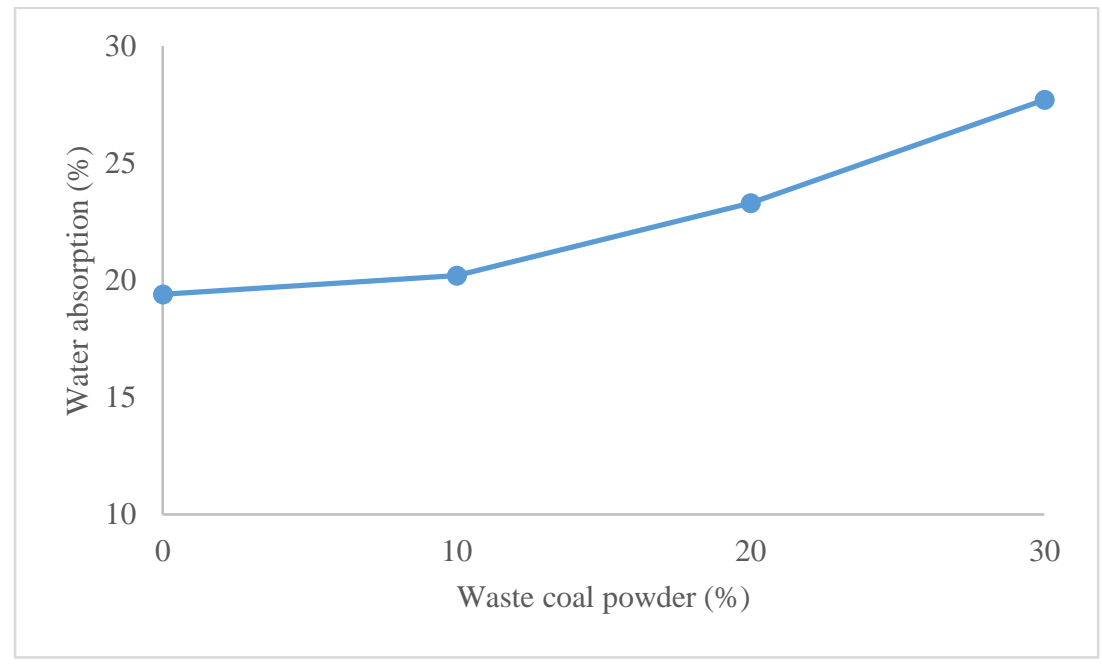

Fig. 7. The effect of coal powder replacement on the waster absorption ratio

\section{Conclusions}

In this study, use of waste coal powder obtained from Soma, Manisa, Turkey, in the production of bricks made up of clay from Kolsuz region, Niğde, Turkey. In the light of the findings, the following results were concluded.

- Unit weights of the samples were determined to have decreased with the increasing ratio of waste coal powder. This has sourced from the fact that coal powder underwent ignition loss at high firing temperatures and thus left the paste.

- Coal powder additive at $10 \%$ ratio increased the compressive and flexural tensile strength values of the samples. 
- Water absorption ratios of the samples generally increased with the increasing coal powder ratio. This shows that waste coal powder additive has caused the porosity of the samples to increase.

The authors suggest that researchers should make further endeavour to produce qualitatively more improved products by using all other miscellaneous clay types found in Niğde quarries that exhibit a rich variety of industrial minerals. Types of other waste materials could be used as additives or coal powder ratios could be diversified further to study more possible effects studied or not yet studied-. These products would absolutely make great contribution to the efforts to create a more sustainable environment within the framework of energy conservation and reuse of waste materials.

\section{References}

1. Kızgut, S., Çuhadaroğlu, D., Çolak, K.: Çatalağzı Termik Santralı uçucu küllerinden tuğla üretim olanaklarının araştırılması, 17. Uluslararası Madencilik Kongresi ve SergisiTUMAKS, 2001, Türkiye.

2. Emrullahoğlu, C.B., Karademir, H., Emrullahoğlu, Ö.F.:Tuğla Kırıklarının Tuğla Üretiminde Kullanımı. 5 Endüstriyel Hammaddeler Sempozyumu, 13-14 Mayıs 2004, İzmir, Türkiye, s.199-203.

3. Demir, İ., Başpınar, M.S., Kahraman, E.: Kırmızı Çamur Katkılı Tuğla Üretiminin Araştırılması", Afyon Kocatepe Üniversitesi Fen ve Mühendislik Bilimleri Dergisi 14 (2014) 537-540.

4. Yıldız, A., Emrullahoğlu, F.: Seydiler (Afyon) Diyatomitinin İzolasyon Tuğlası Olarak Kullanılabilirliğinin Araştırılması. Afyon Kocatepe Üniversitesi Fen ve Mühendislik Bilimleri Dergisi 1(1) (2015) 65-76.

5. Bideci, A., Sallı Bideci, Ö.: Diatomit Hammaddesinin Tuğla Üretiminde Kullanılabilirliğinin Araştırılması. Trakya University Journal of Engineering Sciences 8(2) (2008) 69-76.

6. Kavas, T., Önce, G.: Etibor Kırka Boraks İşletmesi Konsantratör Atıklarının Pres Tuğla Üretiminde Ergitici Eleman Olarak Kullanılabilirliği. I. Uluslararası Bor Sempozyumu, 2002, Kütahya, Türkiye, 219-223.

7. Bentli, İ., Uyanık, A.O., Demir, U., Şahbaz, O., Çelik, M.S.: Seyitömer Termik Santrali Uçucu Küllerinin Tuğla Katkı Hammaddesi Olarak Kullanımı. Türkiye 19. Uluslararası Madencilik Kongresi ve Fuarı. /MCET2005, 09-12 Haziran 2005, İzmir, Türkiye, s.385389.

8. Çelik, M.H., Kanıt,R., Orhan, M.: Isparta Bölgesi Pomzasının Tuğla Üretiminde Kullanılabilirliğinin Araştırılması”, Politeknik Dergisi 6(3) (2003) 597-604.

9. Kayalı, R., Gürel A., Davarcıoğlu, B., Çiftçi, E.:Orta Anadolu Bölgesi'ndeki Endüstriyel Hammaddelerinden Kil ve Diyatomitlerin Spektroskopik Yöntemlerle Nitelik ve Niceliklerinin Belirlenmesi Raporu”, TÜBİTAK Rapor No: ÇAYDAG-101Y067, 2005.

10. TS EN 1015-11, Kagir Harc1-Deney Metotları-Bölüm 11: Sertleşmiş Harcın Basınç ve Eğilme Dayanımının Tayini, Türk Standartları Enstitüsü, Ankara, 2000.

11. TS 3624, 1981. Sertleşmiş Betonda Özgül Ağırlık, Su Emme ve Boşluk Oranı Tayin Metodu. Türk Standartları Enstitüsü, Ankara, 1981. 